\title{
Association between PSEN1 p.E318G Variant and APOE Polymorphism and Alzheimer Disease in Turkish Patients
}

\author{
Türk Hastalarda PSEN1 p.E318G Varyantı ile APOE Polimorfizmi ve Alzheimer Hastalı̆̆ı \\ Arasındaki İlişki
}

\begin{abstract}
Objective: Mutations in the Presenilin-1 (PSEN1) gene have been associated with early-onset familial Alzheimer disease (AD) and these mutations usually exhibit full penetrance. However, the p.E318G variant located at exon 9 of PSEN1 is an exception. This variant is also seen in non-demented controls other than patients with $\mathrm{AD}$ suggesting that it may be a rare polymorphism or a mutation with low penetrance. In addition, results from studies conducted in different populations investigating the role of p.E318G variant in AD were conflicting. In this study, we aimed to determine the frequency of the PSEN1 p.E318G variant and $A P O E$ genotypes in a Turkish cohort and to investigate whether they were associated with the risk of AD.

Materials and Methods: The study included 217 patients with familial AD, 153 patients with sporadic AD, and 402 controls. The PSEN1 p.E318G and $A P O E$ genotypes were determined using real-time polymerase chain reaction with hydrolysis probes.

Results: The p.E318G variant was found in five patients with familial AD, three patients with sporadic AD, and 11 control subjects. There was no significant difference in the distribution of the p.E318G variant between patients and controls in familial and sporadic forms. APOE $\varepsilon 4$ allele carriers had an increased risk for AD compared with non-carriers both in familial [odds ratio (OR): 3.67, 95\% confidence interval (CI): (2.69-4.99); p<0.001] and sporadic cases [OR: 2.91, 95\% CI: (2.06-4.10); $\mathrm{p}<0.001]$. No significant difference was found in the distribution of the p.E318G variant with either the absence or presence of the $A P O E$ $\varepsilon 4$ allele.

Conclusion: Our results showed that PSEN1 p.E318G variation, either alone or together with the APOE $\varepsilon 4$ allele, is not associated with AD risk in Turkish patients with $\mathrm{AD}$. However, the $A P O E \varepsilon 4$ allele constitutes a significant risk factor for $\mathrm{AD}$ both in familial and sporadic forms.
\end{abstract}

Keywords: Alzheimer disease, presenilin-1, E318G variant, $A P O E \varepsilon 4$

$\ddot{O} z$

Amaç: Presenilin-1 (PSEN1) genindeki mutasyonlar, erken başlangıçlı ailevi Alzheimer hastalığı (AH) ile ilişkilendirilmiştir ve bu mutasyonlar çoğunlukla tam penetrans gösterir. Ancak PSEN1 geninin 9 ekzonundaki p.E318G varyantı bunlar içinde bir istisnadır. p.E318G varyantının AH hastaları dışında demans olmayan kontrollerde de gösterilmesi, onun nadir bir polimorfizm ya da düşük penetranslı bir mutasyon olabileceğini düşündürmektedir. Bu varyantın AH'de patojenik rolü olup olmadığını araştıran ve birçok farklı popülasyonda gerçekleştirilen çalışmalarda çelişkili sonuçlar elde edilmiştir. Bu çalışmada, AH hastalarında ve kontrollerde PSEN1 p.E318G varyantının ve APOE genotiplerinin sıklı̆̆ını belirlemeyi ve Türk kohortunda AH riski ile ilişkili olup olmadıklarını araştırmayı amaçladik.

Gereç ve Yöntem: Çalışmaya 217 ailevi AH ve 153 sporadik AH hastası ve 402 kontrol dahil edildi. Hasta ve kontrollerin p.E318G ve APOE genotipleri hidroliz problar kullanılarak gerçek zamanlı polimeraz zincir reaksiyonu yöntemi ile belirlendi.

Address for Correspondence/Yazışma Adresi: Gamze Güven MD, İstanbul University, Aziz Sancar Institute of Experimental Medicine, Department of Genetics, İstanbul, Turkey

Phone: +90 5324701093 E-mail: zgamzee@ gmail.com ORCID: orcid.org/0000-0001-8576-5843

Received/Geliş Tarihi: 09.06.2020 Accepted/Kabul Tarihi: 01.02.2021

${ }^{\circledR}$ Copyright 2021 by Turkish Neurological Society

Turkish Journal of Neurology published by Galenos Publishing House. 


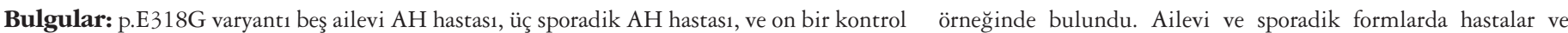

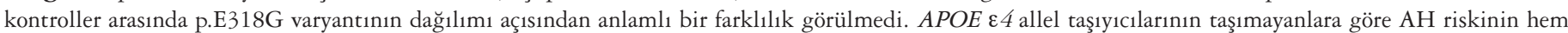

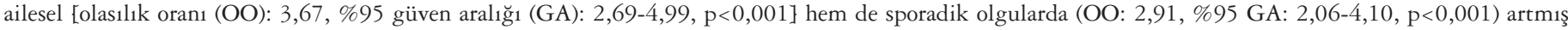

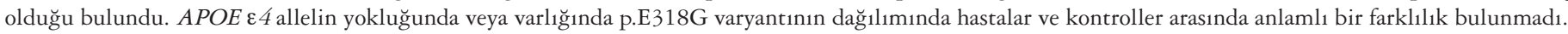

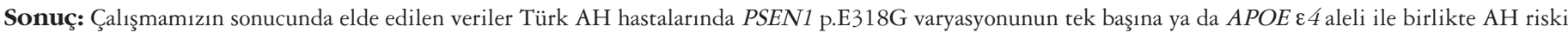

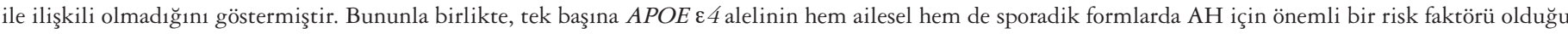
görülmüştür.

Anahtar Kelimeler: Alzheimer hastalı̆ $\breve{g}_{1}$, presenilin-1, E318G varyasyonu, APOE ع 4

\section{Introduction}

Alzheimer's disease (AD) is the most common cause of dementia seen in older adults. A common approach currently accepted according to the age of onset is to categorize $\mathrm{AD}$ into early-onset Alzheimer's disease [(EOAD); age at onset $<65$ years], and lateonset Alzheimer's disease [(LOAD; age at onset $>65$ years]. EOAD is mostly familial, and $10-15 \%$ of patients with familial EOAD exhibit an autosomal dominant transmission (1). Autosomal dominantly inherited EOAD has been associated with pathogenic variants in the "Amyloid precursor protein (APP)", "Presenilin 1 (PSEN1)", and "Presenilin 2 (PSEN2)" genes. Pathogenic variants in PSEN1 gene are found in about $30-70 \%$ of familial EOAD cases and are associated with the most aggressive forms of the disease (2). The PSEN1 gene encodes a transmembrane protein containing 467 amino acids, which cleaves APP into beta-amyloid peptides (A $\beta$ ) through gamma-secretase activity. Mutations in the PSEN1 gene cause an increase in the $A \beta 42 / A \beta 40$ ratio by impairing proteolytic cleavage of APP by gamma-secretase, and as a result, accumulation of $A \beta$ plaques (3). To date, more than 300 mutations in PSEN1 have been reported as pathogenic in the Human Gene Mutation Database (HGMD; www.hgmd.org).

One of the PSEN1 variations considered to be associated with $A D$ is the p.E318G variation (rs17125721) $(4,5)$. This variation occurs due to an A to $\mathrm{G}$ transition at codon 318 in PSEN1 exon 9 and leads to a non-conserved glutamic acid to glycine substitution. Results from studies conducted in different populations suggested that the pathogenicity of p.E318G in AD is controversial and it could be either an incompletely penetrant mutation or a rare polymorphism not associated with AD (6). It has been shown that the p.E318G variant was associated with high levels of total tau and phospho-tau in cerebrospinal fluid (4). Furthermore, coexistence of p.E318G variant with the APOE \&4 allele was associated with amyloid deposition and faster episodic memory decline (4). In the present study, our aim was to investigate the frequency of the p.E318G variant both in patients with sporadic and familial AD and controls and to evaluate its association with the $A P O E \& 4$ allele in a Turkish cohort.

\section{Materials and Methods}

\section{Patients and Controls}

The study population comprised 370 patients with AD and 402 controls without any history of major, systemic, psychiatric, and neurologic disease. The participants were recruited in the department of neurology, behavioral neurology and movement disorders unit, and underwent comprehensive clinical and neuropsychological examinations and neuroimaging. AD was diagnosed according to the National Institute of Neurological and Communicative Disorders and Stroke and AD (7). Approval was obtained from the Ethics Committee of İstanbul Universityİstanbul Faculty of Medicine, Clinical Research Ethics Committee (decision no: 1209, date: 17/10/2016). The study was performed in line with the principles of the Declaration of Helsinki. Written and signed informed consent was obtained from all participants or legal guardians for subjects unable to consent.

\section{Genotyping}

Genomic DNA was isolated from peripheral blood leukocytes according to standard procedures. Screening of the PSEN1 E318G variant was performed using quantitative real-time polymerase chain reaction (RT-qPCR) with a Taqman SNP Genotyping Assay (assay ID: C__ 589147_10, Thermo Fischer Scientific Inc.). A total of $10 \mu \mathrm{L}$ qPCR reaction mix was composed of $0.5 \mu \mathrm{L}$ TaqMan Genotyping Assay (Applied Biosystems), $5 \mu \mathrm{L}$ LightCycler 480 Probes Master (Roche), $2.5 \mu \mathrm{L}$ RNase-free water and $2 \mu \mathrm{L}$ DNA $(50 \mathrm{ng} / \mu \mathrm{L})$. The qPCR was performed on a LightCycler480 system (Roche) under the following conditions: $95{ }^{\circ} \mathrm{C} 10 \mathrm{~min}$, 45 cycles of $95^{\circ} \mathrm{C} 15 \mathrm{~s}$, and $60^{\circ} \mathrm{C} 1 \mathrm{~min}$. APOE genotypes were determined using RT-PCR with hydrolysis probes. The APOE RT amplifications included $10 \mathrm{~min}$ at $95^{\circ} \mathrm{C}$; 45 cycles of $10 \mathrm{sec}$ at 95 ${ }^{\circ} \mathrm{C}$; $30 \mathrm{sec}$ at $56{ }^{\circ} \mathrm{C}$ and $1 \mathrm{sec}$ at $72{ }^{\circ} \mathrm{C}$. The end-point analysis was assessed using the LightCycler 480 genotyping software.

\section{Statistical Analysis}

Student's t-test was used for normally distributed continuous variables and Fisher's exact test for categorical variables. Maximum likelihood estimates of odds ratios (OR) and the 95\% confidence intervals (CI) were calculated using binary logistic regression analysis. The SPSS software was used for all statistical analyses (IBM Corp., USA, version 21.0). P values below 0.05 were regarded as statistically significant.

\section{Results}

Patients with AD were divided into two groups: familial AD (at least one first-degree relative with a history of dementia) and sporadic AD (no family history of dementia). The characteristics of the study population are given in Table 1 . A total of 370 patients with AD including 217 patients with familial (mean age: $64.6 \pm 10.7$ years) and 153 patients with sporadic AD (mean age: $66.6 \pm 11.4$ years).

As shown in Table 2, the p.E318G variant was found in five $(2.3 \%)$ patients with familial AD and three (2\%) with sporadic $\mathrm{AD}$ and in $11(2.7 \%)$ control subjects. The p.E318G variant was detected only in the heterozygous state and no homozygous carriers were found. No significant difference in distribution of p.E318G was found for familial AD vs. controls $(p=0.746)$ and sporadic AD vs controls $(\mathrm{p}=0.767)$. 
In all groups, the distribution of allele frequencies and genotypes of $A P O E$ was significantly different $(\mathrm{p}<0.001)$ between patients and controls (Table 3 ). The $\varepsilon 3 / \varepsilon 4$ and $\varepsilon 4 / \varepsilon 4$ genotypes were found to be more common in the patient groups than in the controls. The APOE $\varepsilon 2, \varepsilon 3, \varepsilon 4$ allele frequencies were $3.9 \%$, $74.1 \%$, and $22 \%$ in patients with familial AD and $2.6 \%, 78.6 \%$, and $18.8 \%$ in patients with sporadic $\mathrm{AD}$, and in the controls, the frequencies were found as $5 \%, 87.3 \%$ and $7.7 \%$, respectively. Individuals with sporadic AD with at least one copy of APOE $\varepsilon 4$ allele had a 2.91-fold increased risk [OR: 2.91, 95\% CI: (2.064.10); $\mathrm{p}<0.001]$ for AD than individuals without the $\varepsilon 4$ allele, and in patients with familial AD, risk increased up to 3.67 fold [OR: 3.67, 95\% CI: (2.69-4.99); $\mathrm{p}<0.001$ ].

To examine the possible interaction of the APOE $\varepsilon 4$ allele and p.E318G variant, we investigated the distribution of p.E318G variant in $\varepsilon 4$ allele carriers and non-carriers. In both the presence and absence of the $A P O E \& 4$ allele, no significant difference was found in the distribution of p.E318G variant between patients and controls in all groups (Table 4). However, there was a weak trend $(\mathrm{p}=0.268)$ for the coexistence of the APOE $\varepsilon 4$ allele and the p.E318G variant in patients with familial AD. Of the five familial p.E318G carriers, three carried at least one copy of the APOE $\varepsilon 4$ allele, but this trend was lacking in controls, as none of the p.E318G carriers were carrying the $\varepsilon 4$ allele.

General characteristics of patients with the PSEN1 p.E318G variant were given in Table 5. Six of the patients were diagnosed with EOAD, one with LOAD and one with atypical dementia. Of the three patients carrying $A P O E \& 4$ allele, two were homozygous and one was heterozygous for $\varepsilon 4$ allele. The mean age at onset of patients was $56.2 \pm 11.2$, range $36-76$ years. The mean age of patients with the PSEN1 p.E318G variant was $60.2 \pm 11$ while controls with the p.E318G variant were younger (mean age \pm standard deviation: $48.6 \pm 11.3)$ than the patients.

\section{Discussion}

In this study, we evaluated the frequency of the p.E318G variant and $A P O E$ genotypes and their contribution to $\mathrm{AD}$ in familial and sporadic forms. Also, we investigated whether there was an association between the p.E318G variant and the APOE $\varepsilon 4$ allele.

The p.E318G variant is located on the hydrophilic loop between transmembrane domain VI and VII of PSEN1 protein (8). This region of the PSEN1 protein is less conserved between its homologues in other species and predicted to be functionally less important (9). The pathogenicity of the p.E318G variant is still under debate. In initial studies, it was considered as pathogenic in patients with $\operatorname{EOAD}(10,11)$; however, its presence in controls and no segregation with disease made its pathogenicity questionable $(2,12,13,14,15,16,17,18)$. Even so, results from studies conducted in different populations investigating the role of p.E318G variant in $\mathrm{AD}$ were conflicting. Evidence from some case-control studies indicated p.E318G as a risk variant for patients with familial AD $(2,12,13,18)$, but other studies found no significant association of p.E318G and AD $(14,16,17,19)$. Therefore, the association between the PSEN1 p.E318G variant and AD remains controversial.

The frequency of the p.E318G variant in our total patients with $\mathrm{AD}(2.1 \%)$ was lower than that described for European populations, actually it was the lowest reported to date (Dutch:

Table 1. General characteristics of patient groups and controls

\begin{tabular}{|c|c|c|c|}
\hline \multicolumn{3}{|c|}{ Patients } & \multirow{2}{*}{ Controls } \\
\hline & Familial AD & Sporadic AD & \\
\hline Number of individuals & 217 & 153 & 402 \\
\hline Age (years) & $64.6 \pm 10.7^{* * *}$ & $66.6 \pm 11.4^{* * *}$ & $57.6 \pm 13.1$ \\
\hline Age at onset, years & $60.4 \pm 10.4$ & $62.3 \pm 11.3$ & - \\
\hline \multicolumn{4}{|l|}{ Gender, n (\%) } \\
\hline Male & $101(46.5)$ & $57(37.3)$ & $183(45.5)$ \\
\hline Female & $116(53.5)$ & $96(62.7)$ & $219(54.5)$ \\
\hline MMSE score & $18.9 \pm 7.7^{* *}(n=143)$ & $16.8 \pm 7.8^{* *}(n=106)$ & $28.9 \pm 2.1 \quad(n=58)$ \\
\hline GDS & $10.3 \pm 5.9 *(n=55)$ & $11.2 \pm 6.2^{*}(\mathrm{n}=41)$ & $7.19 \pm 6.3(n=27)$ \\
\hline
\end{tabular}

Table 2. Distribution of PSEN1 E318G variant in patient groups and controls

\begin{tabular}{|c|c|c|c|}
\hline & \multicolumn{2}{|c|}{ Patients $(n=370)$} & Controls $(n=402)$ \\
\hline E318G+ & $5(2.3)$ & $3(2)$ & $11(3.2)$ \\
\hline OR $(95 \% \mathrm{CI})$ & $0.84(0.29-2.44)$ & $0.71(0.19-2.58)$ & - \\
\hline $\mathrm{p}$ value & $0.746^{\mathrm{a}}$ & $0.767^{\mathrm{b}}$ & - \\
\hline
\end{tabular}




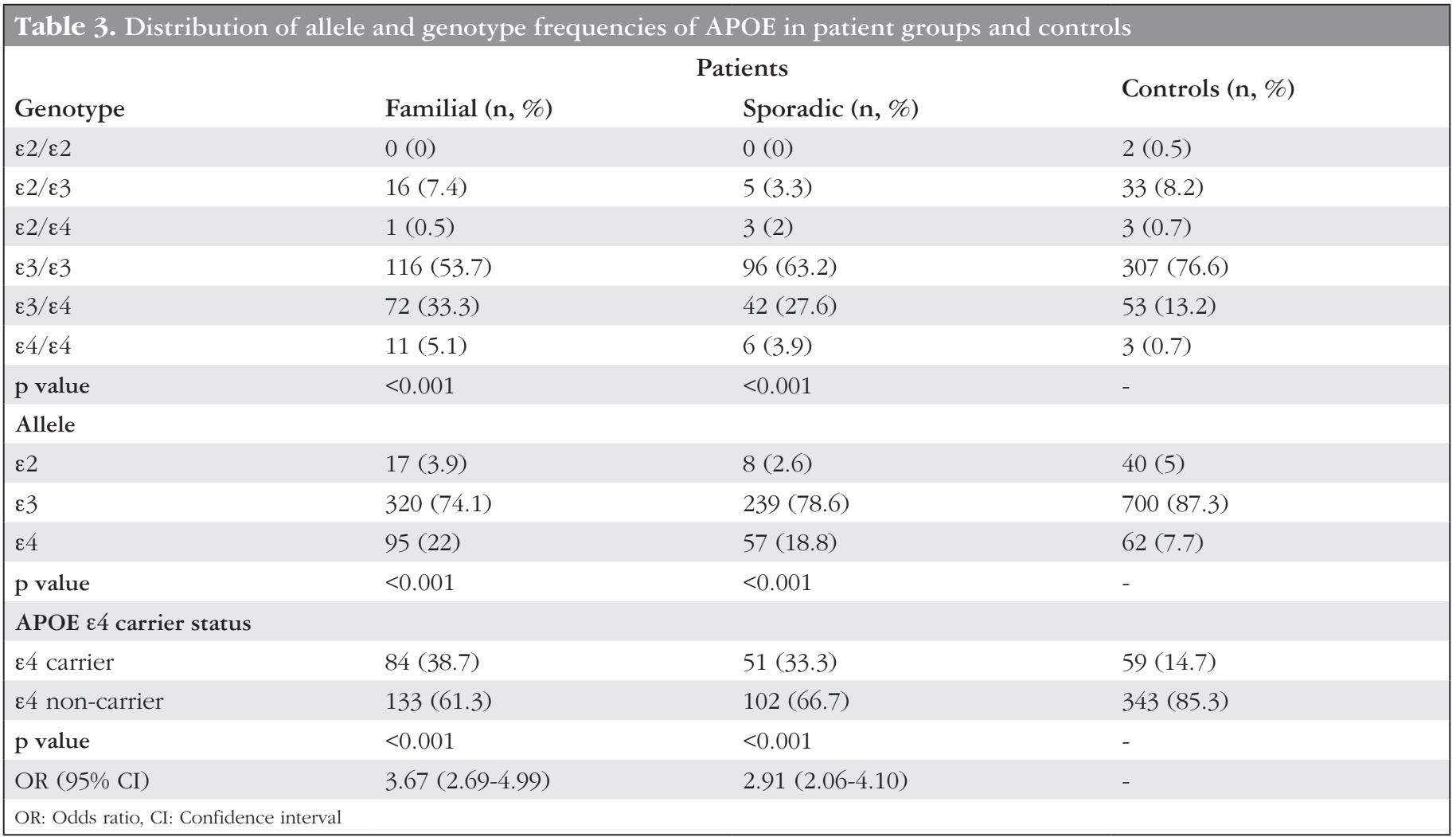

Table 4. Distribution of PSEN1 E318G variant in patient groups and controls stratified for APOE 84 status

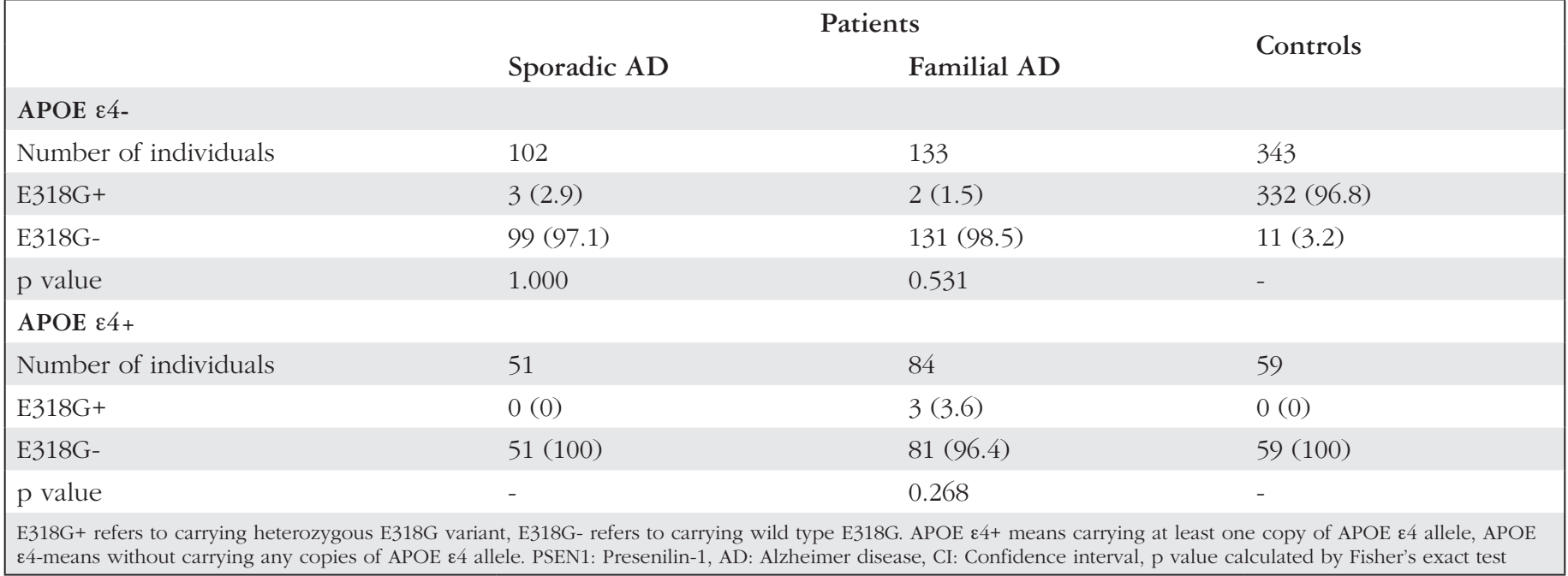

$2.7 \%$, Italian: $3.3 \%$, French: $3.5 \%$, Finnish: $6.6 \%$, Spanish: $6.7 \%$, Australian: $3.6 \%$, and Brazilian: $4 \%)(13,14,15,16,19)$. Similarly, the frequency of the variant in our control group (2.7\%) was lower than the reported frequencies for European populations (Finnish: 6.8\%, Spanish: $4.5 \%$, Dutch: $4.1 \%$, French: $4.1 \%$, Polish: $4.0 \%$ ) $(14,15,16,17,19)$, but has similar frequency with the Australian population (2.2\%) (12). Comparing the frequency of the p.E318G variant in patients with familial $A D$ with those of other populations, our population has the lowest frequency $(2.3 \%)$, but the frequency in patients with sporadic $\mathrm{AD}(2 \%)$ was consistent with the results from previous studies $(2,12,13)$. Despite the larger number of patients included in our study, our results did not validate the previously reported significant associations of the p.E318G variant with AD. The lack of association between p.E318G variant and AD in our study is in agreement with previous studies that showed no significant associations either in patients with sporadic or familial $\mathrm{AD}$ in different populations $(14,16,17,19)$. Combined with our results, these data suggested that the association between the p.E318G variant and AD might vary among different populations. 


\begin{tabular}{|c|c|c|c|c|c|c|}
\hline ID & Age & $\mathrm{AAO}$ & Sex & Family history & APOE status & MMSE \\
\hline Patient 1 & 61 & 59 & Female & Familial & $\varepsilon 4 / \varepsilon 4$ & 23 \\
\hline Patient 2 & 60 & 57 & Female & Familial & $\varepsilon 3 / \varepsilon 3$ & 19 \\
\hline Patient 3 & 67 & 63 & Female & Sporadic & $\varepsilon 3 / \varepsilon 3$ & NA \\
\hline Patient 4 & 56 & 53 & Male & Sporadic & $\varepsilon 3 / \varepsilon 3$ & 9 \\
\hline Patient 5 & 39 & 36 & Male & Familial & $\varepsilon 3 / \varepsilon 3$ & NA \\
\hline Patient 6 & 77 & 76 & Female & Familial & $\varepsilon 3 / \varepsilon 4$ & 12 \\
\hline Patient 7 & 66 & 53 & Male & Familial & $\varepsilon 4 / \varepsilon 4$ & 22 \\
\hline Patient 8 & 56 & 53 & Female & Sporadic & $\varepsilon 3 / \varepsilon 3$ & 9 \\
\hline
\end{tabular}

The association between $A P O E$ gene and AD risk has been studied in a great number of populations. Studies showed that the frequencies of $A P O E \varepsilon 2, \varepsilon 3$ and $\varepsilon 4$ alleles varied between populations due to geographic locations and different ethnicities, but in most of them, the $\varepsilon 4$ allele was considered as a risk factor for $\mathrm{AD}$. In our study, the $A P O E \varepsilon$ allele frequencies in patients with $\mathrm{AD}$ and controls were very similar to those reported in the Turkish population $(20,21,22,23)$ but were lower than in other populations (23). The low frequency of the $A P O E \varepsilon 4$ allele both in our study and previous studies is in line with the observation that $\varepsilon 4$ frequency is low in Mediterranean countries. Our data confirm a clear association between $A P O E \& 4$ allele and AD; we found that the $\varepsilon 4$ allele increased $A D$ risk in patients with $A D$ with a higher OR in patients with familial AD. The combined effect of $P S E N 1$ polymorphisms and APOE $\varepsilon$ alleles on AD risk has been investigated previously in Turkish patients with LOAD; however, no significant difference was found (24).

The coexistence of the APOE \&4 allele and the p.E318G variant is associated with higher amyloid plaque deposition, faster episodic memory decline, and subsequent increased AD risk (4). In their study, Benitez et al. (4) showed that p.E318G variant modified $\mathrm{AD}$ risk in $A P O E \& 4$ carriers and increased the $\mathrm{AD}$ risk equally to $\varepsilon 4$ homozygous in $\varepsilon 4$ heterozygous; they showed that the PSEN1 p.E318G carriers who also carried the APOE $\varepsilon 4$ allele were at higher risk of developing $\mathrm{AD}$ than carriers of p.E318G variant alone, and had twice the risk of AD than those carrying the APOE \&4 allele alone (4). Therefore, to investigate the association of $A P O E \& 4$ allele and PSEN1 p.E318G, we examined the distribution of p.E318G variant in $A P O E \varepsilon 4$ allele carriers. Although no significant association was found, our study highlighted the tendency for the coexistence of at least one copy of the $A P O E \varepsilon 4$ allele and the p.E318G variant in patients with familial AD.

\section{Study Limitations}

This study has limitations as follows. First, due to the small number of p.E318G carriers in this study, it is difficult to assess the significance of tendency for the coexistence of the $A P O E \varepsilon 4$ allele and the p.E318G variant in patients with familial AD. Further investigations in larger case-control series are necessary to confirm this association in the Turkish population because PSEN1 p.E318G variant and APOE \& 4 interaction is an important modifier of AD risk. Secondly, controls carrying the p.E318G variant were aged younger than 60 years and might later develop the disease; therefore, prospective follow-up examinations should be considered in controls. Another limitation of this study was that the control group was significantly younger than the patient group; this may not affect the results of the frequency of PSEN1 p.E318G variation or $A P O E \& 4$ allele, but Mini-Mental State Examination scores may have been affected. Finally, another limitation was our relatively small sample size; the results of this study will be strengthened by studies with larger study groups.

\section{Conclusion}

In our study, we do not provide evidence for the association of the PSEN1 p.E318G variant with AD risk and its interaction with the $A P O E \& 4$ allele. In addition, our results claim that the $A P O E \varepsilon 4$ allele is a significant risk factor in $\mathrm{AD}$ in the Turkish population. As far as we know, our study is the first to investigate the role of E318G variant in Turkish patients with AD. Therefore, further analyses in larger case-control cohorts are necessary to fully understand the effect of p.E318G on AD risk in the Turkish population. We suggest that special consideration should be taken in the interpretation of PSEN1 p.E318G variant in AD, especially in familial forms.

\section{Acknowledgements}

The authors would like to thank the patients and families for their generous participations.

Ethics

Ethics Committee Approval: Approval was obtained from the Ethics Committee of İstanbul University-İstanbul Faculty of Medicine, Clinical Research Ethics Committee (decision no: 1209, date: 17/10/2016).

Informed Consent: Written and signed informed consent was obtained from all participants or legal guardians for subjects unable to consent.

Peer-review: Externally and internally peer-reviewed.

\section{Authorship Contributions}

Surgical and Medical Practices: H.H., E.L., H.G., B.B., Concept: G.G., N.E.Ü., B.B., Design: G.G., N.E.Ü., R.A., Ç.D., Data Collection or Processing: G.G., H.H., E.L., H.G., R.A., Ç.D., Analysis or Interpretation: G.G., H.H., E.L., N.E.Ü., H.G., B.B., 
Literature Search: G.G., R.A., Ç.D., Writing: G.G.

Conflict of Interest: No conflict of interest was declared by the authors.

Financial Disclosure: This work was supported by the Research Fund of Istanbul University (project no: 35352).

\section{References}

1. Cacace R, Sleegers K, Van Broeckhoven C. Molecular genetics of early-onset Alzheimer's disease revisited. Alzheimers Dement 2016;12:733-748.

2. Abdala BB, dos Santos JM, Gonçalves AP, et al. Influence of low frequency PSEN1 variants on familial Alzheimer's disease risk in Brazil. Neurosci Lett 2017;653:341-345.

3. Artuso V, Benussi L, Ghidoni R, et al. Asymptomatic carriers of presenilin-1 E318G variant show no cerebrospinal fluid biochemical signs suggestive of alzheimer's disease in a family with late-onset dementia. Curr Alzheimer Res 2018;16:1-7.

4. Benitez BA, Karch CM, Cai Y, et al. The PSEN1, p.E318G variant increases the risk of alzheimer's disease in APOE- $\varepsilon 4$ carriers. PLoS Genet 2013;9:e1003685. doi:10.1371/journal.pgen.1003685

5. Hippen AA, Ebbert MTW, Norton MC, et al. Presenilin E318G variant and Alzheimer's disease risk: The Cache County study. BMC Genomics 2016;17(Suppl 3):10-14.

6. Cruts M, Van Broeckhoven C. Presenilin mutations in Alzheimer's disease. Hum Mutat 1998;11:183-190.

7. McKhann GM, Knopman DS, Chertkow H, et al. The diagnosis of dementia due to Alzheimers disease: Recommendations from the National Institute on Aging-Alzheimer's Association workgroups on diagnostic guidelines for Alzheimer's disease. Alzheimer's Dement 2011;7:263-269.

8. Vetrivel KS, Zhang YW, Xu H, Thinakaran G. Pathological and physiological functions of presenilins. Mol Neurodegener 2006;1:1-12.

9. Cruts M, Van Duijn CM, Backhovens H, et al. Estimation of the genetic contribution of presenilin-1 and -2 mutations in a population-based study of presenilin Alzheimer disease. Hum Mol Genet 1998;7:43-51.

10. Sandbrink R, Zhang D, Schaeffer S, et al. Missense mutations of the PS-1/ S182 gene in German early-onset Alzheimer's disease patients. Ann Neurol 1996;40:265-266.

11. Forsell C, Froelich S, Axelman K, et al. A novel pathogenic mutation (Leu262Phe) found in the presenilin 1 gene in early-onset Alzheimer's disease. Neurosci Lett 1997;234:3-6.
12. Taddei K, Fisher C, Laws SM, et al. Association between presenilin-1 Glu318Gly mutation and familial Alzheimer's disease in the Australian population. Mol Psychiatry 2002;7:776-781.

13. Albani D, Roiter I, Artuso V, et al. Presenilin-1 mutation E318G and familial Alzheimer's disease in the Italian population. Neurobiol Aging 2007;28:1682-1688.

14. Mattila KM, Forsell C, Pirttilä T, et al. The Glu318Gly mutation of the presenilin-1 gene does not necessarily cause Alzheimer's disease. Ann Neurol 1998;44:965-967.

15. Dermaut B, Cruts M, Slooter AJ, et al. The Glu318Gly substitution in presenilin 1 is not causally related to Alzheimer disease. Am J Hum Genet 1999;64:290-292.

16. Aldudo J, Bullido MJ, Frank A, Valdivieso F. Missense mutation E318G of the presenilin-1 gene appears to be a nonpathogenic polymorphism. Ann Neurol 1998;44:985-986.

17. Zekanowski C, Pepłońska B, Styczyńska M, et al. The E318G substitution in PSEN1 gene is not connected with Alzheimer's disease in a large Polish cohort. Neurosci Lett 2004;357:167-170.

18. Helisalmi S, Hiltunen M, Mannermaa A, et al. Is the presenilin-1 E318G missense mutation a risk factor for Alzheimer's disease? Neurosci Lett 2000;278:65-68.

19. Cousin E, Macé S, Rocher C, et al. No replication of genetic association between candidate polymorphisms and Alzheimer's disease. Neurobiol Aging 2011;32:1443-1451

20. Yokes M, Emre M, Harmanci H, et al. The apolipoprotein E (APOE) genotype in a Turkish population with Alzheimer's disease. Balkan J Med Genet 2005;8:57-63.

21. Aslan D, Ercan F, Aybek H, Şahiner T. Apoe epsilon4 allele frequency in patients with dementia in different ethnic and geographic groups. Turkish J Biochem 2010;35:163-171.

22. Alaylığlu M, Gezen-Ak D, Dursun E, et al. The association between clusterin and APOE polymorphisms and late-onset alzheimer disease in a Turkish cohort. J Geriatr Psychiatry Neurol 2016;29:221-226.

23. Çilingir O, Adapınar Özbabalık BD, Aras BD, et al. Association between alzheimer disease and APOE gene polymorphisms in Turkish population. Osmangazi J Med 2020;42:222-230.

24. Karaduman T, Eroglu E, Saglar Ozer E, et al. Screening for mutations in the coding regions Of PSEN1 gene, 16-17 exons of APP gene and APOE genotyping in patients with alzheimer's disease. Türk Doğa ve Fen Dergisi 2020;9:35-41. 